\title{
Whey as a substrate for generation of bioelectricity in microbial fuel cell using E.coli
}

\author{
*S. Nasirahmadi; A. A. Safekordi \\ Department of Engineering, Science and Research Branch, Is lamic Azad University, Tehran, Iran \\ Received 21 October 2010; $\quad$ revised 4 January 2011; accepted 9 August 2011; available online 1 September 2011
}

\begin{abstract}
While oil prices raise and the supply remains unsteady, it may be beneficial to use the high content of energy available in food processing wastes, such as cheese whey waste, by converting it to bioenergy. As well, there have been many new waste biotreatment technologies developed recently, which may well be used directly to food processing wastes. Microbial fuel cell represents a new technology for simultaneous use of waste materials and bioelectricity generation. In this study, bioelectricity generation with whey degradation was investigated in a twochamber microbial fuel cell with mediators. E.coli was able to use the carbohydrate found in whey to generate bioelectricity. The open-circuit voltage in absence of mediator was $751.5 \mathrm{mV}$ at room temperature. The voltage was stable for more than $24 \mathrm{~h}$. Riboflavin and humic acid were used as conceivable mediators. The results showed that humic acid was a few times more effective than Riboflavin. Additionally, four chemicals employed as catholyte. Based on polarization curve, $\mathrm{FeCl}_{3}$ (鹿) was the best. Maximum power generation and current were $324.8 \mathrm{i} \mathrm{W}$ and 1194.6ìA, respectively.
\end{abstract}

Keywords: Bioelectricity; Catholyte; Cheese whey; Mediator; Microbial fuel cell

\section{INTRODUCTION}

Various waste types of food industries have been generated in twenty-first century. The environmental upshots of these are earnest patch tending unprocessed because of their inebriated Chemical oxygen demand (COD) values. It is obvious that bioenergy can be extracted through breaking the chemical bonds of the wastes. The waste disposal costs and impacts on the environment will be reduced by doing this simultaneously. Due to oil price and unbalance of its supplies, it may be beneficial to use the eminent energy values in substance of processing wastes, such as cheese whey waste, by bioconverting it to alternative energy. Moreover, there have been several new waste treatment methods or systems developed recently, which may be applied directly to food processing waste. One of these proper technologies is Microbial fuel cell (MFC). This technology traverses its minority scene as research and development. (Perkins, 2002; Chaudhuri and Lovley, 2003; Logan, 2005; Rabaey and Verstraete, 2005b; Chien and Shih, 2007;

*Corresponding Author Email: s.nasirahmadi@gmail.com Tel./ Fax: 09112152985
Venkata Mohan et al. 2007; Venkata Mohan et al., 2008). MFC is a device that catalyzes the bioconversion of organic matter into bioelectricity by organisms like bacteria (Suzuki et al., 1978; Wingard et al., 1982; Allen and Bennetto, 1993; Kim et al., 2002; Bond and Lovley, 2003; Gil et al., 2003; Liu et al., 2004; Goho, 2004; Oh et al., 2004). There is an ardency need in the world today for alternative forms of bioenergy production. This research applied MFC technology to generate bioenergy. While the technology of MFC is not new, recent developments have brought the technology to a more prosperous and practical step. A group of researchers has appraised the effect of different substrates on the performance of microbial fuel cell (Chae et al., 2009). Electrons produced by the bacteria are conveyed to the anode electrode and flow to the cathode ones linked by a conductive material containing a resistor or operated under a load. Electrons are able to be transferred to the anode by mediators, shuttles (Rabaey et al., 2004; Rabaey et al., 2005a) and nanowires (Beveridge, 2004; Reguera et al., 2005). Some Chemical mediators, such as neutral red (Park 
et al., 1999), anthraquinone-2-6, disulfonate (AQDS), thionin, potassium ferricyanide (Bond et al., 2002) and methyl viologen (Logan, 2004) were used to increase the efficiency of power generation in MFCs.

In most MFCs characteristically in two-chamber one, the reached electrons in cathode compartment combine with diffused protons from the anode compartment via a membrane and oxygen originated from atmosphere. Hence, the aftereffect is water formation (Kim et al., 1999; Park and Zeikus, 1999; Kim et al., 2002; Min and logan, 2004). A group of researchers substantiated the unnecessary action of exogenous electron mediators adding to a culture in MFCs (Jang et al., 2004; Rabaey et al., 2004; Rabaey et al., 2005b). These self-produced mediators, such as pyocyanin that is elicited by Pseudomonas aeruginosa, are able to transfer emancipated electrons to an electrode and produce bioelectricity in MFCs (Rabaey et al., 2004). Such compounds also exhibit the characterization of antibiotics. Thus, one main reason for conclusion of these compounds from the angle may be as respiratory inhibitors or toxins emancipation (Hernandez et al., 2004; Voggu et al., 2006). Additionally, multifarious types of electron mediators were applied in MFC to improve the electron transfer efficiency while they are conventionally high-priced and not applicable to be used in commercialscale and they can be noxious to living organism for extendable lifetimes (Gil et al., 2003). The goal of the present research was to ascertain MFCs for power generation using the treated whey as substrate with the least operational manipulation and four cathodic electron acceptors (catholyte). The performance of present MFC for power production using two mediators was investigated. The main goal of the present study was to investigate the bioconversion of treated whey to bioelectricity using E.coli in the anode chamber of MFC. The research work was carried out during 2009 to 2010 at Biotechnology laboratory in the Department of Chemical Engineering, Noshirvani University of Technology, Babol mostly by corresponding author's private and own funds and partially at Islamic Azad University, Science and Research branch, Department of Engineering, Scanning electron microscope (SEM) laboratory, Tehran, Iran.

\section{MATERIALS AND METHODS}

Cheese whey was obtained from Gela dairy product Industry (Amol, Iran). Whole whey solution was uniformly acidified by acid solution $(\mathrm{HCl}, 2 \mathrm{~N})$ at acidic
$\mathrm{pH}$ to remove excessive proteins. The solution was autoclaved at $15 \mathrm{psig}, 121^{\circ} \mathrm{C}$ for $15 \mathrm{~min}$, then cooled down to room temperature, centrifuged at $7,000 \mathrm{x} g$ in sterilized tubes for $15 \mathrm{~min}$ to remove aggregated solids. The supernatant (whey supernatant), was refrigerated for $12 \mathrm{~h}$ and it was used after fixing $\mathrm{pH}$ to 7 by the concentrated $\mathrm{NaOH}$ solution $(10 \mathrm{M})$, as the major constitutive of media for the ontogeny of microorganism. E.coli was supplied by laboratory of Rohani Hospital (Babol, Iran). The microorganisms were grown in an anaerobic jar vessel. Riboflavin, humic acid and cathodic electron acceptors were supplied by Merck (Germany). These chemicals with low concentration $(200 \mu \mathrm{mol} / \mathrm{L}$ and $1 \mathrm{~g} / \mathrm{L})$ were used as mediators in MFC, respectively. The schematic diagram of the fabricated MFC is shown in Fig. 1.The fabricated cells in the laboratory scale were made of glass (Plexy) material. The volume of each chamber (anode and cathode chambers) was $910 \mathrm{~mL}$ with working volume of $800 \mathrm{~mL}$. Sampling access port was provided for the anode, input wire point and the inlet. The selected electrodes in MFC were graphite in size of $40 \times 90 \times 3$ $\mathrm{mm}$. Proton exchange membrane (PEM, Nafion 117, Sigma-Aldrich) was used to separate the two compartments. All chemicals and reagents used in the experiments were analytical grade and supplied by Merck (Germany). PH-meter, Hana 211 (Romania) was a model glass electrode used to measure $\mathrm{pH}$ levels in the aqueous phase. DNS method was developed to detect and measure substrate consumption using colorimetric method (Thomas and Chamberlin, 1980) and cell growth was also monitored by optical density using spectrophotometer (Unico, USA). Also, sodium disulfite $(1 \mathrm{~g} / \mathrm{L})$ was added to anode compartment to minimize oxygen crossover phenomenon during operation that can result in a loss of electron donor due to aerobic respiration by bacteria like E.coli, lowering overall Coulombic efficiency. As it is known, this is the first time of using sodium disulfite as an initiative work in MFCs. Also, a further study with more focus on sodium disulfite is, therefore, suggested.

\section{The medium and inoculum preparation}

The medium prepared for seed culture consisted of glucose, yeast extract, $\mathrm{NH}_{4} \mathrm{Cl}$, peptone: $10,1,0.5$, and 1 $\mathrm{g} / \mathrm{L}$, respectively. The medium was sterilized, autoclaved at $121^{\circ} \mathrm{C}$ and $15 \mathrm{psig}$ for $20 \mathrm{~min}$. The treated whey was used as carbon source and the whey's carbohydrate was considered lactose. The medium 
pH was initially adjusted to 7 and the inoculum was introduced then the culture was incubated at $30^{\circ} \mathrm{C}$. E.coli was fully grown for duration of $24 \mathrm{~h}$ in $100 \mathrm{~mL}$ flux without any agitation. Samples were drawn in interval of $4 \mathrm{~h}$ and substrate consumption was analyzed based on reduced sugar by Dinitrosalicylic acid (DNS) method (Thomas and Chamberlin, 1980).

\section{Nafion proton exchange membrane and electrodes} pretreatment

Nafion was subjected to a course of pretreatment to take off any impurities that were simmering the film for $1 \mathrm{~h}$ in $3 \% \mathrm{H}_{2} \mathrm{O}_{2}$, washed with deionized water, $0.5 \mathrm{M}$ $\mathrm{H}_{2} \mathrm{SO}_{4}$ and then washed with deionized water. The anode and cathode compartments were filled by deionized water when the MFC was not in use to maintain membrane for good conductivity. Electrodes were also subjected to a course of pretreatment that was soaking in $100 \%$ ethanol for $45 \mathrm{~min}$ and in $1 \mathrm{M} \mathrm{HCl}$ for $1 \mathrm{~h}$. After each use, the electrodes were washed in 1.0 M HCL followed by $1.0 \mathrm{M} \mathrm{NaOH}$, each for $1 \mathrm{~h}$, to remove potential metal and organic contamination then stored in distilled water before use (Chae et al., 2008).

\section{Data acquisition system}

Analog digital data acquisition was fabricated to register data point in every $6 \mathrm{~s}$. The system had measurements for variable resistances which were imposed to the MFC. The current in MFC was recorded, dividing the obtained voltage by the defined resistance. Then, the system provides power calculation by multiplication of voltage and current. In addition, the online system determines polarization graphs for power generation and MFC voltage with respect to current. The online system can operate automatically on manually while it operates in auto-mode, the assembled relays are able to regulate automatically the resistances. Voltage of MFC was amplified and then data was transmitted to a microcontroller by an accurate analog to digital converter. The microcontroller also sends the primary data to a computer by serial connection. Moreover, special function of MATLAB software 7.4 was used to store and synchronically display the obtained data.

\section{RESULTS AND DISCUSSION}

The schematic diagram of the fabricated MFC cell shown in Fig. 1, was used for power generation using whey as carbon source. The low-cost feed source was used for power production. The role of mediators as electron shuttle was investigated. Fig. 2 shows opencircuit voltage recorded for the MFC in period over $90 \mathrm{~h}$. Initially, the voltage was less than $400 \mathrm{mV}$ and then gradually increased. At this stage, carbon sources are utilized and products are formed. After 60 $\mathrm{h}$ of operation, Open-circuit voltage (OCV) reached to a maximum value of $751.5 \mathrm{mV}$. The OCV was completely stable for more than $24 \mathrm{~h}$. Finally, rapid utilization of substrate and accumulation of products may lead to stationary phase where the cell density and voltage remains constant. After $30 \mathrm{~h}$, cell may start to die as the cell growth rate balances the death rate. It is well known that the biocatalytic activities of the cell gradually decrease as they age. In other words, the instability was a result of lactose depletion in the anode compartment after $30 \mathrm{~h}$. Figs. $3 \mathrm{a}$ and $3 \mathrm{~b}$ show polarization curve presence of Riboflavin and humic acid as mediator without using any catholyte. Figs. 4, 5, 6 and 7 show polarization curves measured in presence of KI, Ca $\left(\mathrm{NO}_{3}\right)_{2} \cdot 4 \mathrm{H}_{2} \mathrm{O}$, $\mathrm{MnCl}_{2} \cdot 4 \mathrm{H}_{2} \mathrm{O}$ and $\mathrm{FeCl} 3$ (嘕). The presented data show power and voltage with respect to current generated in the MFC without using any magnet stirrer or buffer solution in cathode compartment. These figures (polarization curves) are documented to show the effect of applied chemicals in power generation. Maximum power generation and current among these catholytes were $324.8 \mu \mathrm{W}$ and 1194.6 $\mu \mathrm{A}$, respectively. Mediators are ordinarily employed to enhance the performance of MFC (Logan, 2004). Electron transfer in anode compartment was promoted by two types of mediators in the present MFC. Riboflavin and humic acid were selected as a mediator in MFC with concentration of $200 \mu \mathrm{mol} / \mathrm{L}$. The mediator in MFC had augmented the power production and cell current. Riboflavin increased the power and current to $3.3 \mu \mathrm{W}$ and $18 \mu \mathrm{A}$, respectively. Fig. $3 \mathrm{~b}$ presents a few folds increased in power and current production by using humic acid as a suitable mediator. The power generation and current production in presence of humic acid was higher than Riboflavin. Maximum power generation was $6.75 \mu \mathrm{W}$ while the current was boosted to the highest value of $34.4 \mu \mathrm{A}$. Moreover, the effect of four cathodic electron acceptors was investigated. The results of present polarization 


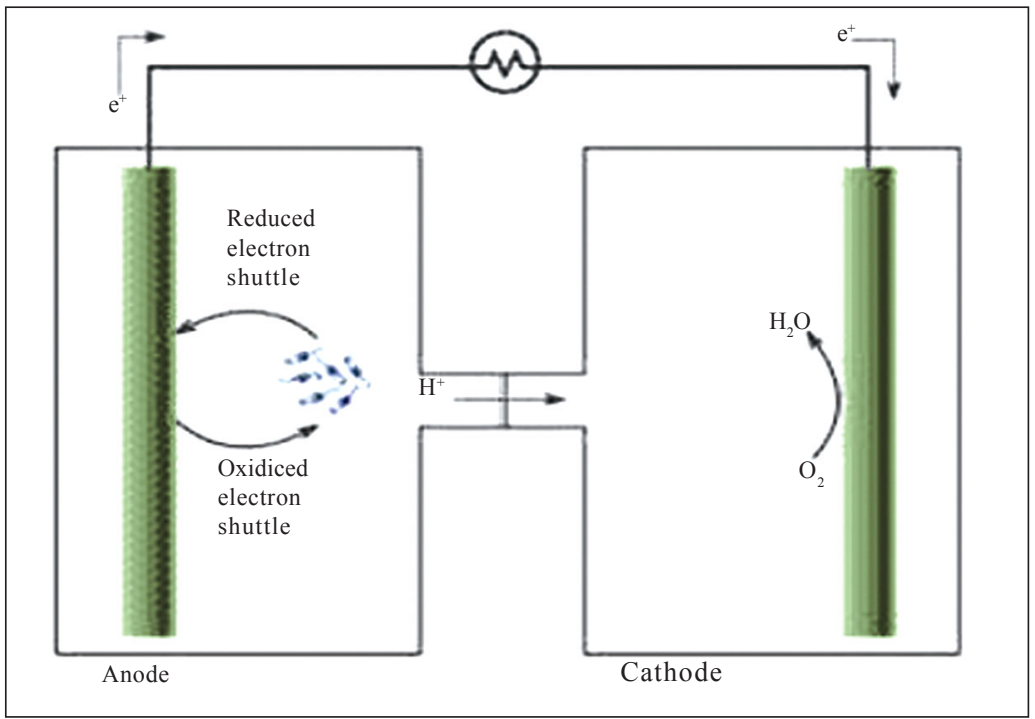

Fig. 1: Schematic diagram of a typical two-chamber MFC applied in the laboratory (After Mario Jardon, 2009)

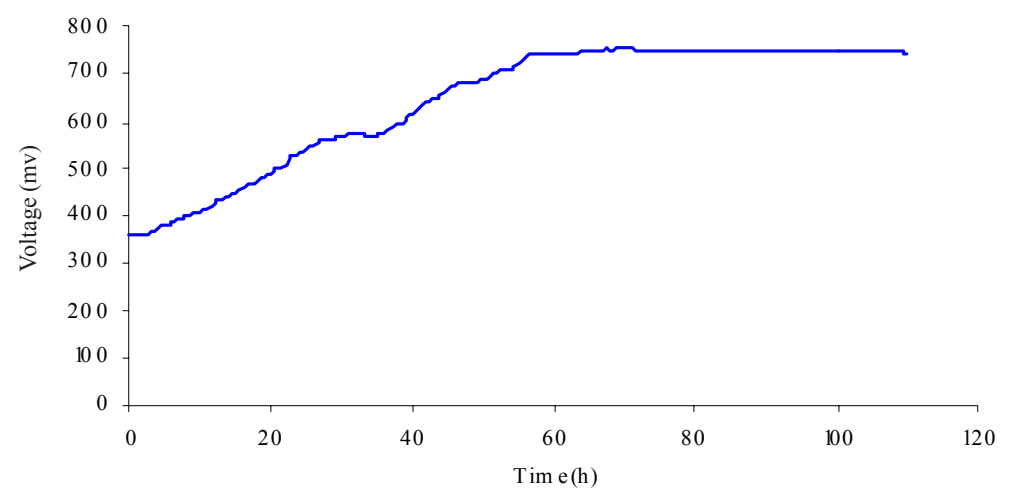

Fig. 2: Open-circuit voltage (OCV) of the MFC

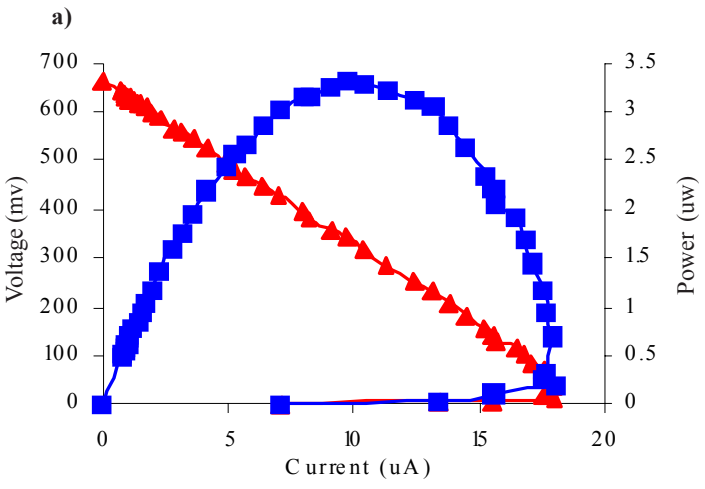

$\longrightarrow$-Voltage (mv) $\rightarrow$-Power (uv)

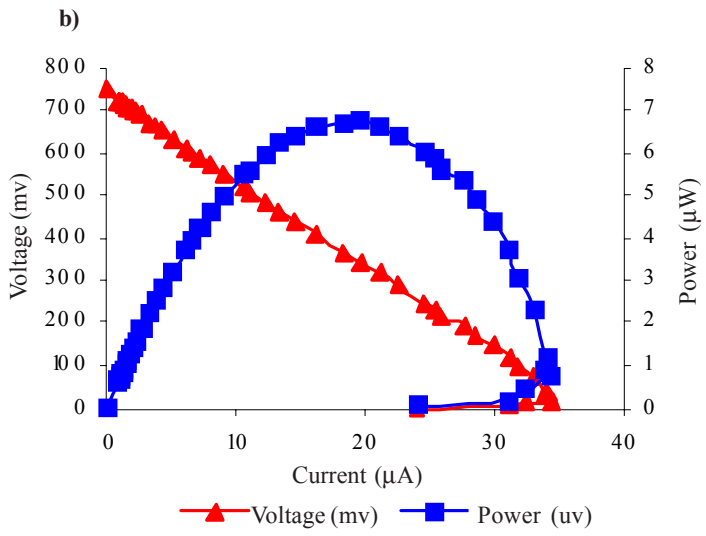

Fig. 3: Polarization curve presence of Riboflavin (a) and polarization curve presence of humic acid (b) 
Int. J. Environ. Sci. Tech., 8 (4), 823-830, Autumn 2011

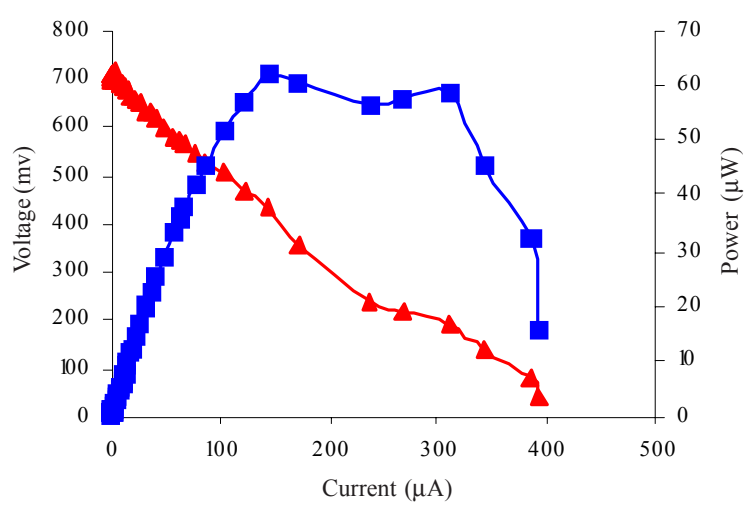

$\longrightarrow$ Voltage (mv) $\rightarrow$ - Power (uv)

Fig. 4: Polarization curve presence of KI as catholyte

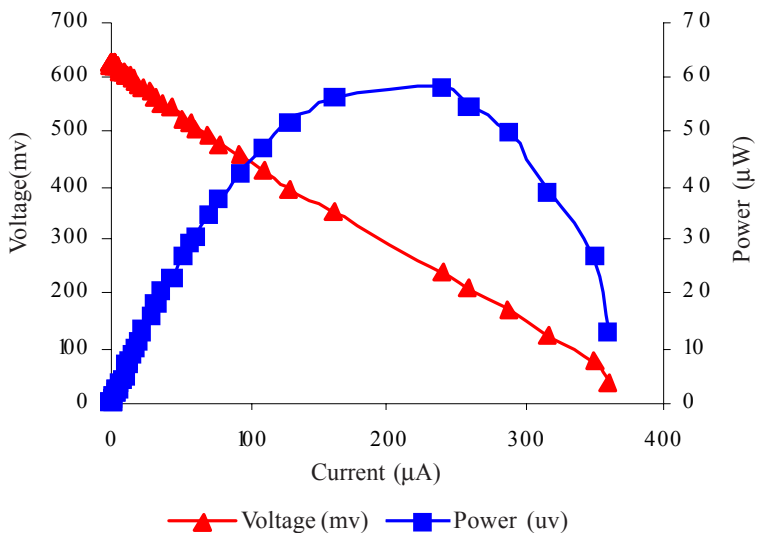

Fig. 5: Polarization curve presence of $\mathrm{Ca}\left(\mathrm{NO}_{3}\right)_{2} \cdot 4 \mathrm{H}_{2} \mathrm{O}$ as catholyte

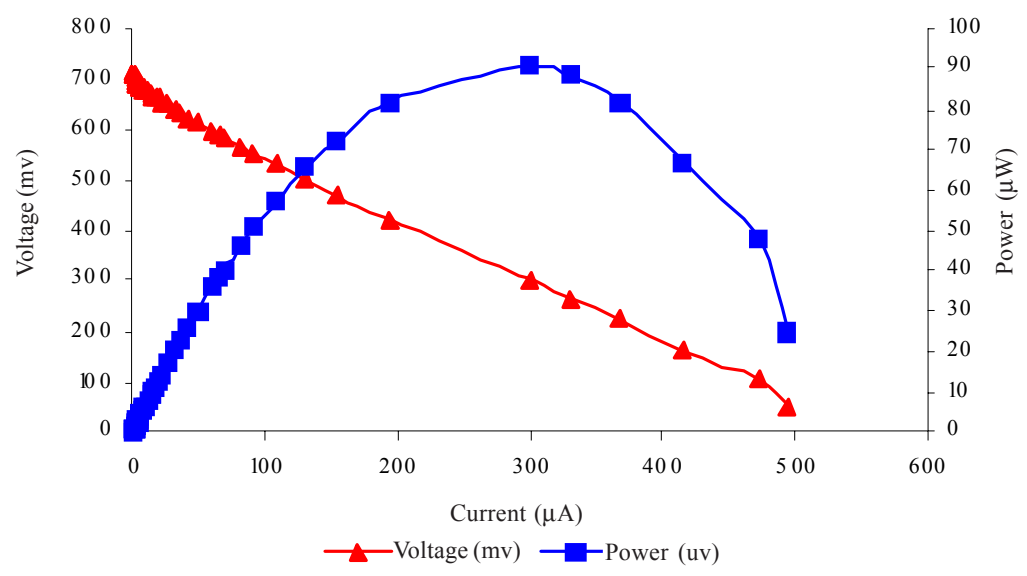

Fig. 6: Polarization curve presence of $\mathrm{MnCl}_{2} \cdot 4 \mathrm{H}_{2} \mathrm{O}$ as catholyte

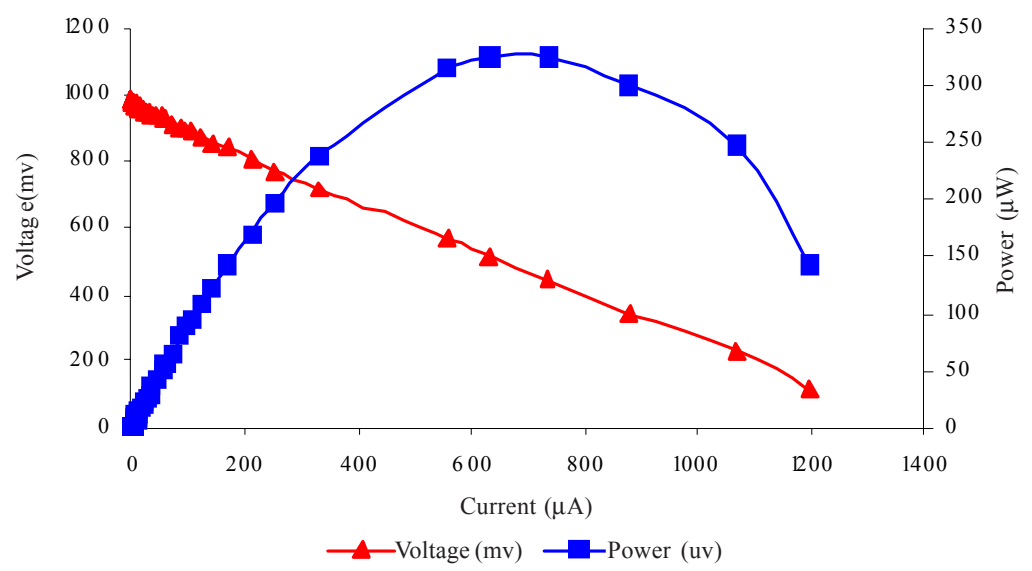

Fig. 7: Polarization curve presence of $\mathrm{FeCl}_{3}$ (III) as catholyte 

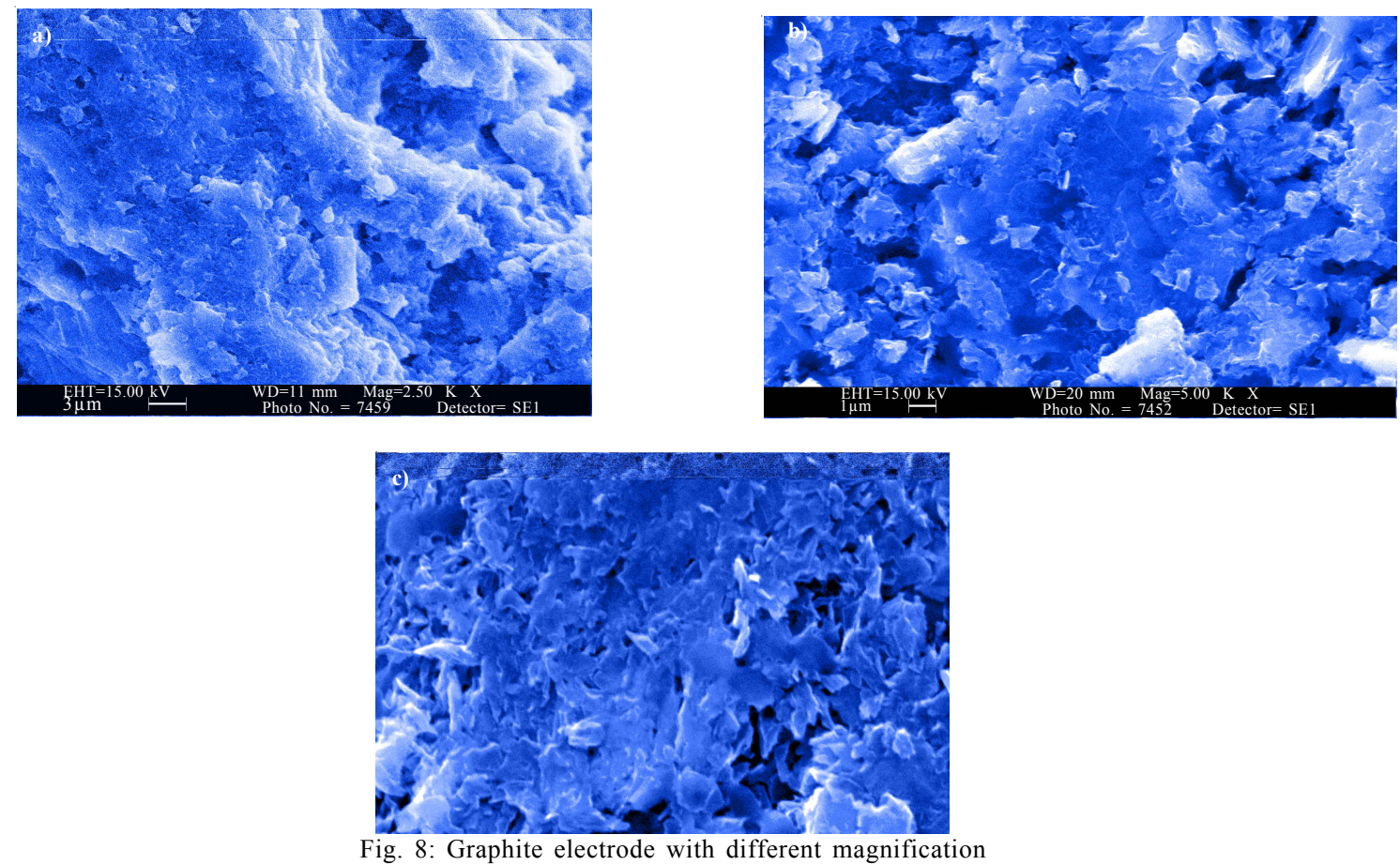

curves shown in Figs. 4, 5, 6 and 7 showed that $\mathrm{FeCl}_{3}$ (雌) was a better choice as catholyte in MFC with values of $324.8 \mu \mathrm{W}$ and $1194.6 \mu \mathrm{A}$, respectively. Figs. $8 \mathrm{a}, 8 \mathrm{~b}$ and $8 \mathrm{c}$ show SEM images. These images demonstrated microorganism and impurities grown on graphite surface. As electrode surface has an important role on MFC efficiency, it is recommended to retreat electrode with that applied method in this paper to surmount efficiency. In addition, the images of the surface characteristic of graphite plate electrode with magnification of 2500, 5000 and 10000 was obtained successfully by SEM. Graphite electrode was removed at the end of experiment and cut into pieces of about $1 \times 1 \mathrm{~cm}$ for SEM analysis. Figs $8 \mathrm{a}, 8 \mathrm{~b}$ and $8 \mathrm{c}$ show the outer surface of the graphite electrode with mentioned magnification respectively. SEM images demonstrated microorganism has grown and impurities accumulated on the graphite surface.

\section{CONCLUSION}

MFC will be a reliable method towards sustainable energy generation soon. These results are promising findings to continue the research of MFC technology using treated whey. Bioelectricity generation was successfully achieved in the MFC. Whey was used as carbon source for production of bioelectricity from E.coli. The MFC performance was enhanced using chemical mediator. Humic acid served as suitable mediator and enhanced the electrical energy. Furthermore, the power and current production was increased to $324.8 \mu \mathrm{W}$ and $1194.6 \mu \mathrm{A}$, respectively. The two-chambered MFC with dairy industry wastewater and E.coli demonstrated their potential for electricity generation. It was also shown that $\mathrm{FeCl}_{3}$ (塶) is a beneficent electron acceptor to ameliorate efficiency in cathode compartment. In addition, the biocatalytic activities of the cell gradually decreased as a result of lactose depletion in the anode compartment. A future work will be done on other technical aspects as well as new developments in the MFC field with treated whey and four chemicals as electron acceptor in cathode compartment of such MFC. According to SEM images, pretreatment of electrodes are needed for the next operation.

\section{ACKNOWLEDGEMENTS}

The authors wish to acknowledge Rohani Hospital in Babol, Iran upon providing E.coli for the MFC operation as cooperation. In addition, authors thank 
Biotechnology Research Center, Noshirvani University of Technology, Babol, Iran for any cooperation to accomplish this research. Finally, authors would also like to thank laboratory of Islamic Azad University, Science and Research Branch, Iran for SEM images.

\section{REFERENCES}

Allen, R. M.; Bennetto, H. P., (1993). Microbial Fuel-Cells: electricity production from carbohydrates. Appl. Biochem. Biotech., 39-40 (1), 27-40 (14 pages).

Beveridge, T. J., (2004). Composition, reactivity, and regulation of extracellular metal-reducing structures (bacterial nanowires) produced by dissimilatory metal reducing bacteria. 01 June. University of Guelph, 1-3 (3 pages).

Bond, D. R.; Lovley, D. R., (2003). Electricity production by Geobacter sulfurreducens attached to electrodes. Appl. Environ. Microb., 69 (3), 1548-1555 (8 pages).

Bond, D. R.; Holmes, D. E.; Tender, L. M.; Lovley, D. R., (2002). Electrode-reducing microorganisms that harvest energy from marine sediments. Sci., 295 (5554), 483-485 (3 pages).

Chae, K. J.; Choi, M. J.; Lee, J. W.; Kim, K. Y.; kim, I. S., (2009). Effect of different substrates on the performance, bacterial diversity and bacterial viability in microbial fuel cells. Bioresour. Tech., 100 (14), 3518-3525 (8 pages).

Chae, K. J.; Choi, M.; Ajayi, F. F.; Park, W.; Chang, I. S.; Kim, I. S., (2008). Mass transport through a proton exchange membrane (Nafion) in microbial fuel cell. Energy and Fuels., 22 (1), 169-176 (8 pages).

Chaudhuri, S. K.; Lovley, D. R., (2003). Electricity generation by direct oxidation of glucose in mediatorless microbial fuel cells. Nat. Biotech., 21, 1229-1232 (4 pages).

Chien, M. K.; Shih, L. H., (2007). An empirical study of the implementation of green supply chain management practices in the electrical and electronic industry and their relation to organizational performances. Int. J. Environ. Sci. Tech., 4 (3), 383-394 (12 pages).

Gil, G. C.; Chang, I. S.; Kim, B. H.; Kim, M.; Jang, J. K.; Park, H. S.; Kim, H. J., (2003). Operational parameters affecting the performance of a mediator-less microbial fuel cell. Biosen. Bioelectro., 18 (4), 327-338 (12 pages).

Goho, A., (2004). Special treatment: Fuel cell draws energy from waste. Science News Web. http://www.sciencenews.org/ articles/20040313/fob5.asp.

Hernandez, M. E.; Kappier, A.; Newman, D. K., (2004). Phenazines and other redox-active antibiotics promote microbial mineral reduction. Appl. Environ. Microbiol., 79 (2), 921-928 (8 pages).

Jang, J. K.; Pham, T. H.; Chang, I. S.; Kang, K. H.; Moon, H.; Cho, K. S.; Kim, B. H., (2004). Construction and operation of a novel mediator and membrane-less microbial fuel cell. Process. Biochem., 39 (8), 1007-1012 (6 pages).

Kim, H. J.; Park, H. S.; Hyun, M. S.; Chang, I. S.; Kim, M.; Kim, B. H., (2002). A mediator-less microbial fuel cell using a metal reducing bacterium, Shewanella putrefacians. Enz. Microb. Tech., 30 (2), 145-152 (8 pages).

Kim, B. H.; Park, D. H.; Shin, P. K.; Chang, I. S.; Kim, H. J.,
(1999). Mediator-less biofuel cell. U.S. Patent., 5976719 (18 pages).

Liu, H.; Ramnarayanan, R.; Logan, B. E., (2004). Production of electricity during waste-water treatment using a single chamber microbial fuel cell. Environ. Sci. Tech., 38 (7), 2281-2285 (5 pages).

Logan, B. E., (2004). Extracting hydrogen and electricity from renewable resources. Environ. Sci. Tech., 38 (9), 160A-167A (8 pages).

Logan, B. E., (2005). Simultaneous wastewater treatment and biological electricity generation. Water. Sci. Tech., 52 (1-2), 31-37 (7 pages).

Min, B.; Logan, B. E., (2004). Continuous electricity generation from domestic waste-water and organic substrates in a flat plate microbial fuel cell. Environ. Sci. Tech., 38 (21), 5809-5814 (6 pages).

Oh, S. E.; Min, B.; Logan, B. E., (2004). Cathode performance as a factor in electricity generation in microbial fuel cells. Environ. Sci. Tech., 38 (18), 4900-4904 (5 pages).

Park, D. H.; Laivenieks, M.; Guettler, M. V.; Jain, M. K.; Zeikus, J. G., (1999). Microbial utilization of electrically reduced neutral red as the sole electron donor for growth and metabolite production. Appl. Environ. Microbiol., 65 (7), 2912-2917 (6 pages).

Park, D. H.; Zeikus, J. G., (1999). Utilization of electrically reduced neutral red by Actinobacillus succinogenes: physiological function of neutral red in membrane-driven fumarate reduction and energy conservation. J. Bacteriol., 181, 2403-2410 (8 pages).

Perkins, S., (2002). Voltage from the bottom of the sea: Ooze-dwelling microbes can power electronics. Science News Web. http://www.sciencenews.org/articles/20020713/ fob5.asp.

Rabaey, K.; Boon, N.; Hofte, M.; Verstraete, W., (2005a). Microbial phenazine production enhances electron transfer in biofuel cells. Environ. Sci. Tech., 39 (9), 3401-3408 (8 pages).

Rabaey, K.; Verstraete, W., (2005b). Microbial fuel cells: novel biotechnology for energy generation. Trends. Biotech., 23, 291-298 (8 pages).

Rabaey, K.; Boon, N.; Siciliano, S. D.; Verhaege, M.; Verstraete, W., (2004). Biofuel cells select for microbial consortia that self-mediate electron transfer. Appl. Environ. Microbiol., 70 (9), 5373-5382 (10 pages).

Reguera, G.; McCarthy, K. D.; Mehta, T.; Nicoll, J. S.; Tuominen, M. T.; Lovley, D. R., (2005). Extracellular electron transfer via microbial nanowires. Nature., 435, 1098-1101 (4 pages).

Suzuki, S.; Karube, I.; Matsunaga, T., (1978). Application of a biochemical fuel cell to wastewaters. Biotech. Bioeng. Sympo., 8, 501-511 (11 pages).

Thomas, L. C.; Chamberlin, G. J., (1980). Colorimetric Chemical Analytical Methods, 9rd. Ed. The Tintometer Ltd, Salisbury. UK. (625 pages).

Venkata Mohan, S.; Saravanan, R.; Veer Raghuvulu, S.; Mohanakrishna, G.; Sarma, P. N., (2008). Bioelectricity production from wastewater treatment in dual chambered microbial fuel cell (MFC) using selectively enriched mixed microflora: effect of catholyte. Bioresour. Tech., 99, 596603 ( 8 pages).

Venkata Mohan, S.; Veer Raghuvulu, S.; Srikanth, S.; Sarma, 
P. N., (2007). Bioelectricity production by mediatorless microbial fuel cell under acidophilic condition using wastewater as substrate: influence of substrate loading rate. Curr. Sci., 92 (12), 1720-1726 (7 pages).

Voggu, L.; Schlag, S.; Biswas, R.; Rosenstein, R.; Rausch, C.; Gotz, F., (2006). Microevolution of cytochrome bd oxidase in Staphylococci and its implication in resistance to respiratory toxins release by Psuedomonas. J. Bacteriol., 188 (23), 8079-8086 (8 pages).

Wingard, L. B. J.; Shaw, C. H.; Castner, J. F., (1982) Bioelectrochemical fuel cells. Enz. Microb. Tech., 4 (3), 137-142 (6 pages).

AUTHOR (S) BIOSKETCHES

Nasirahmadi, S., M.Sc. student, Department of Engineering, Science and Research Branch, Islamic Azad University, Tehran, Iran. Email s.nasirahmadi@gmail.com

Safekordi, A. A., Ph.D., Professor, Department of Engineering, Science and Research Branch, Islamic Azad University, Tehran, Iran. Email: safekordi@sharif.ir

How to cite this article: (Harvard style)

Nasirahmadi, S.; Safekordi, A. A., (2011). Whey as a substrate for generation of bioelectricity in microbial fuel cell using E.coli. Int. J. Environ. Sci. Tech., 8 (4), 823-830. 